ISSN 2503-2682 (Online)

ISSN 2503-3654 (Cetak)

\title{
Analisis Perbandingan Karakteristik, Biaya dan Waktu Material Dinding Komposit dan Non Komposit
}

\author{
Lila Khamelda ${ }^{1}$, Benedictus Sonny Yoedono ${ }^{2}$, Anna Catharina S.P.S ${ }^{3}$ \\ 1,2,3 Jurusan Teknik Sipil, Fakultas Teknik, Universitas Katolik Widya Karya \\ e-mail : lila@widyakarya.ac.id
}

\begin{abstract}
ABSTRAK
Perkembangan kebutuhan akan hunian telah mendorong inovasi material dinding yang bersaing dari berbagai segi. Dinding merupakan struktur rumah yang dapat bersifat struktural, non struktural atau sebagai partisi. Penelitian ini bertujuan untuk memberikan pilihan material dinding pada rumah tipe 38 yaitu material non komposit (bata) dan komposit (beton/bata ringan (AAC), batako, M-Panel). Bata, AAC dan batako merupakan material yang telah umum digunakan, sedangkan M-Panel belum terlalu umum digunakan. M-panel merupakan material komposit yang berbentuk panel atau plat (papan tipis) yang dapat digunakan sebagai dinding, tangga, atap dan lantai. Analisa Harga Satuan Pekerjaan terhadap konstruksi dinding dalam penelitian ini menggunakan AHSP Dirjen PU 2016. Ditemukan bahwa biaya terendah untuk aplikasi material dinding diperoleh dari batu bata dan sebaliknya yang tertinggi diperoleh dari M-Panel. Juga ditemukan bahwa durasi terpendek diperoleh dari M-Panel dan durasi terpanjang diperoleh dari batako. Karakteristik material yang didapatkan dari responden tidak sepenuhnya memenuhi proposisi peneliti, diperkirakan hal tersebut disebabkan karena kurangnya pengetahuan terkait salah satu material yaitu M-Panel.
\end{abstract}

Kata Kunci : SNI; m-panel; AAC

The development of residential needs has encouraged the innovation of wall materials that competitive in various aspects. Walls are home structures that can be structural, non-structural or as partitions. This study aims to provide a choice of wall materials in houses type 38, which are covering non-composite (brick) and composite materials (concrete) light brick (AAC), concrete brick (batako), M-Panel). Brick, AAC and concrete brick are commonly used, while M-Panel is not too commonly used. M-panel is a composite material in the form of panels or plates (thin boards) that can be used as walls, stairs, roofs and floors. Work. Unit Price Analysis of wall construction in this study uses AHSP Director General of Public Works 2016. It is found that the lowest cost for wall material application is obtained by brick and the contrary the bighest is obtained by M-Panel. It is also found that the shortest duration is obtained by M-Panel and the longest is obtained by concrete brick. Material characteristics obtained from respondents did not fully fulfill the researchers' propositions, it was estimated that things were caused by a lack of knowledge regarding one of the materials, namely the M-Panel.

Keywords : SNI, m-panel, AAC

\section{PENDAHULUAN}

Perkembangan kebutuhan akan hunian menuntut adanya berbagai inovasi dalam pengadaan material, tidak terkecuali material dinding. Hal tersebut tidak hanya disebabkan oleh peningkatan permintaan yang menyebabkan sumber daya material konvensional semakin langka dan menipis tetapi juga masalah waktu, dimana kebutuhan untuk mempercepat waktu 
produksi semakin menjadi fokus utama selain biaya yang ekonomis.

Menanggapi permasalahan yang timbul, pihak-pihak yang terkait dengan konstruksi selalu berupaya menemukan terobosan dan inovasi baru. Inovasi tersebut memberikan banyak keuntungan bagi berbagai pihak, terutama konsumen sebagai pihak pengguna inovasi tersebut. Adapun kontribusi dari penelitian ini adalah memberikan informasi terkait material inovasi. Disadari bahwa banyak inovasi yang terkait dengan material dinding, maka dalam penelitian ini dilakukan tinjauan terhadap material dinding yaitu bata, beton ringan, batako dan m-panel. Bata dan batako tidak termasuk dalam inovasi baru, tetapi dalam penelitian ini tidak hanya bertujuan untuk menginformasikan mengenai pilihan material dinding tetapi juga perbandingan keuntungan dan kerugian meliputi sifat material, biaya dan waktu pelaksanaan antara material konvensional dengan material baru.

Dinding merupakan bagian dari bangunan yang berdasarkan fungsi terbagi atas 3 jenis yaitu dinding struktural, non struktural dan partisi (1).

Bata adalah batu buatan yang berbahan utama tanah liat. Ukuran bata bervariasi tergantung pada daerah produsen. Bata diproduksi secara manual dan fabrikasi, yang melalui proses pencetakan kemudian dibakar. Bata merah umumnya memiliki ukuran panjang $17-23 \mathrm{~cm}$, lebar $7-$ $11 \mathrm{~cm}$, tebal 3-5 cm (2).

Autoclaved Aerated Concrete (AAC) adalah beton ringan yang dibuat dari bahan baku seperti pasir silika, semen dan bahan campuran lain yang dikategorikan sebagai bahan-bahan untuk beton ringan. Sejak tahun 1980-an, AAC semakin banyak digunakan dalam industri konstruksi di berbagai belahan dunia dikarenakan karakteristik AAC yang ringan tapi kuat, sehingga sangat membantu dalam mengurangi biaya struktur bangunan. AAC juga dikenal sebagai bahan yang memiliki sifat insulasi temperatur dan kedap suara yang baik, serta ramah lingkungan. (3)

Batako adalah bahan bangunan yang terbuat dari campuran bahan perekat, agregat, dan air. Itu sebabnya, beberapa orang menyebut batako sebagai bata beton. Kebanyakan batako memiliki ukuran panjang 36-40 cm, tebal $8-10 \mathrm{~cm}$, dan tinggi $18-20 \mathrm{~cm}$. Penggunaan batako biasanya diterapkan dalam pembangunan dinding non-struktural. Berdasarkan Persyaratan Umum Bahan Bangunan di Indonesia tahun 1982 pasal 6, pengertian batako ialah bata yang dibuat dengan mencetak dan memelihara dalam kondisi lembab. Sementara menurut SNI 03-0349-1989 menyebutkan bahwa batako atau conblock (concrete block) atau batu cetak beton adalah komponen bangunan yang dibuat dari campuran semen portland atau pozolan, pasir, air, dan atau tanpa bahan tambahan lainnya (additive), dicetak sedemikian rupa hingga memenuhi syarat dan dapat digunakan sebagai bahan untuk pasangan dinding. Ketentuan ini juga mengatur persyaratan nilai penyerapan air maksimum pada batako yakni 25 persen.

M-panel adalah material konstruksi yang berbentuk panel yang merupakan panel EPS (expanded polystrene). M-panel mempunyai ketebalan $4-32 \mathrm{~cm}$, dapat direkatkan dengan plester konvensional. Komponen dasar dari m-panel adalah polyfoam dan jaring (net kawat baja (wiremesh)). Polyfoam merupakan bahan yang tidak beracun, tidak berbahaya, tidak mudah terbakar dan tidak memiliki kimia aktif. Sedangkan jaringnya terbuat dari 
kawat baja yang telah digalvanis, diletakkan di kedua panel polyfoam dan saling terhubung satu sama lain. M-panel tersedia dalam bentuk single panel PSM (untuk dinding), single panel PST untuk partisi, double panel (untuk dinding bangunan tingkat tinggi), floor panel (untuk lantai), dan staircase (untuk tangga) (4).
Pelaksanaan penelitian yang diawali dengan identifikasi masalah kemudian dilanjutkan dengan previous research review dimana telah cukup banyak dilakukan penelitian terhadap material dinding. Penelitian terdahulu dirangkum dalam tabel berikut.

Tabel 1. Penelitian Terdahulu

\begin{tabular}{|c|c|c|}
\hline No. & Judul, Nama Peneliti & Metode dan Hasil Penelitian \\
\hline 1 & $\begin{array}{l}\text { Analisa Produktivitas Pemasangan } \\
\text { Dinding dengan Material M-Panel } \\
\text { EPS (Expanded Polystyrene System) } \\
\text { (M. Ilham Akbar I. (2014)) (5). }\end{array}$ & $\begin{aligned} & \text { Metode daily record sheet dan baseline productivity. } \\
\text { - } & \text { Waktu pekerjaan dinding M-Panel }\left(5550 \mathrm{~m}^{2}\right) \text { pada tiap } \\
& \text { jenis pengamatan adalah: pemasangan }=12,704 \mathrm{~m}^{2} / \mathrm{jam}, \\
& \text { plester tahap I }=108,890 \mathrm{~m} 2 / \text { jam, plester tahap II }= \\
& 28,343 \mathrm{~m}^{2} / \text { jam. } \\
- & \text { Harga satuan pekerjaan dinding tiap } \mathrm{m}^{2} \text { sebesar Rp } \\
& 219,441.13 \text { sehingga total biaya pekerjaan dinding seluas } \\
& 5550 \mathrm{~m} 2 \text { sebesar Rp } 1.217 .898 .271,50 .\end{aligned}$ \\
\hline 2 & $\begin{array}{l}\text { Analisis Perbandingan Waktu dan } \\
\text { Biaya dalam Penggunaan Bata } \\
\text { Merah dengan M-Panel EPS } \\
\text { (Expanded Polystyrene System) (Heny } \\
\text { Purwanti (2014)) (6). }\end{array}$ & $\begin{array}{l}\text { - } \text { Metode daily record sheet dan baseline productivity. } \\
\text { - Biaya material pekerjaan dinding bata merah lebih murah } \\
\text { dibandingkan dengan pekerjaan dinding } \mathrm{m} \text {-panel. } \\
\text { - Upah tenaga kerja untuk pekerjaan dinding m-panel } \\
\text { lebih murah dibandingkan dengan pekerjaan dinding } \\
\text { bata merah karena waktu pelaksanaan pekerjaan yang } \\
\text { lebih cepat. }\end{array}$ \\
\hline 3 & $\begin{array}{l}\text { Analisis Perbandingan Biaya Dan } \\
\text { Waktu Pekerjaan Dinding } \\
\text { Menggunakan Bata Merah Dengan } \\
\text { M-Panel (G.A.P Candra } \\
\text { Dharmayanti, I Gusti Ketut } \\
\text { Sudipta, Gede Tusan Saputra } \\
\text { (2016)) (7). }\end{array}$ & $\begin{array}{l}\text { - Metode daily record sheet dan baseline productivity. } \\
\text { - Jumlah tenaga untuk bata merah sejumlah } 4 \text { orang dan } \\
\text { M-panel sejumlah } 5 \text { orang. } \\
\text { - M-panel membutuhkan biaya yang lebih tinggi sebesar } \\
\text { 30\% dari dinding bata merah. } \\
\text { - Pengerjaan dinding M-panel seluas } 1000 \mathrm{~m}^{2} \\
\text { membutuhkan } 10 \text { hari kerja sedangkan bata merah } \\
\text { membutuhkan } 63 \text { hari kerja. }\end{array}$ \\
\hline 4 & $\begin{array}{l}\text { Perhitungan Harga Satuan } \\
\text { Pekerjaan Dinding Bata Ringan } \\
\text { dengan Metode SNI dan Ms } \\
\text { Project pada Proyek Pembangunan } \\
\text { Gedung Laboratorium } \\
\text { Enterpreneurship Terpadu } \\
\text { Universitas Brawijaya Malang } \\
\text { (Kartika Puspa Negara, Saifoe El } \\
\text { Unas, Hamzah Hasyim, Marchel } \\
\text { Aditha (2015)) (8). }\end{array}$ & $\begin{array}{l}\text { - } \text { Metode SNI dan Ms. Project } \\
\text { - Perhitungan biaya pekerjaan dengan SNI didapatkan } \\
\text { sebesar Rp 2,4 M, sedangkan dengan Ms Project sebesar } \\
\text { Rp 1,9 M. } \\
\text { - Hasil perhitungan dengan Ms Project lebih mendekati } \\
\text { keadaan di lapangan. }\end{array}$ \\
\hline 5 & $\begin{array}{l}\text { Analisa Produktivitas Pekerjaan } \\
\text { Dinding Panel, Dinding Batu Bata } \\
\text { Konvensional, dan SNI Pekerjaan } \\
\text { Dinding (Saifoe El Unas, Kartika } \\
\text { Puspa N., Rifky Rezha Pranata }\end{array}$ & $\begin{array}{l}\text { - } \text { Metode Daily Record Sheet, Baseline Productivity, SNI } \\
\text { - Nilai produktivitas pekerjaan dinding panel pada tiap } \\
\text { jenis pengamatan adalah: pemasangan }=12,723 \mathrm{~m}^{2} / \text { jam, } \\
\text { plester tahap I }=108,814 \mathrm{~m}^{2} / \text { jam, plester tahap II = } \\
\text { 28,346 } \mathrm{m}^{2} / \text { jam, sedangkan nilai produktifitas pekerjaan }\end{array}$ \\
\hline
\end{tabular}




\begin{tabular}{|c|c|c|c|}
\hline No. & \multicolumn{2}{|r|}{ Judul, Nama Peneliti } & Metode dan Hasil Penelitian \\
\hline & \multicolumn{2}{|c|}{ Yudha (2015)) (9). } & $\begin{array}{l}\text { dinding bata adalah pemasangan }=3,00 \mathrm{~m}^{2} / \mathrm{jam} \text {, plester } \\
=3,57 \mathrm{~m}^{2} / \mathrm{jam} \text { dan dinding bata berdasarkan SNI adalah } \\
\text { pemasangan }=1,33 \mathrm{~m}^{2} / \text { jam, plester }=1,00 \mathrm{~m}^{2} / \text { jam. } \\
\text { - Harga satuan pekerjaan dinding Panel tiap } \mathrm{m}^{2} \text { sebesar } \\
\mathrm{Rp} 211.271,72 \text { sedangkan dinding bata sebesar Rp } \\
\text { 84.258,98 dan dinding bata berdasarkan SNI sebesar Rp. } \\
\text { 130.422,08. }\end{array}$ \\
\hline 6 & $\begin{array}{l}\text { Obyek } \\
\text { Metode }\end{array}$ & $\begin{array}{ll}: & \text { Analisa Produktifitas } \\
& \text { Dinding Bata Ringan } \\
& \text { Dan Dinding Precast } \\
& \text { Pada Bangunan } \\
& \text { Gedung Tinggi } \\
& \text { Hunian } \\
: & \text { Retna Kristiana, Aan } \\
& \text { Pujiandi (2016) (10) } \\
: & \\
: \text { Daily Record Sheet, } & \text { Baseline Productivity } \\
\end{array}$ & $\begin{array}{l}\text { - Harga bata ringan terpasang Rp. } 484.175,-/ \mathrm{m}^{2} \text {, waktu } \\
\text { pemasangan bata ringan } \pm 12 \text { bulan. Harga pemasangan } \\
\text { bata ringan bervariasi tiap lantainya, semakin tinggi } \\
\text { lantainya semakin mahal harganya. } \\
\text { - Analisa produktifitas dinding precast adalah harga } \\
\text { material dinding precast Rp. } 279.000,-/ \mathrm{m}^{2} \text {, harga } \\
\text { pemasangan dinding precast Rp. } 277.000,-/ \mathrm{m}^{2} \text {, total } \\
\text { harga pemasangan dinding precast Rp. } 4.567 .206 .000 \text {,- } \\
\text { sehingga harga terpasang dinding precast Rp. } 556.000 \text {,- } \\
/ \mathrm{m}^{2} \text {, waktu pemasangan dinding precast } \pm 7 \text { bulan. }\end{array}$ \\
\hline 7 & \multicolumn{2}{|c|}{$\begin{array}{l}\text { Analisa Perbandingan Estimasi } \\
\text { Biaya dan Waktu pada Pekerjaan } \\
\text { Dinding Bata Merah, Batako, dan } \\
\text { Bata Ringan pada Gedung (Gusti } \\
\text { Reza Fairuzz (2018)) (11) }\end{array}$} & $\begin{array}{l}\text { - Metode Analisa Harga Satuan SNI } \\
\text { - } \text { Biaya pekerjaan untuk bata merah sebesar Rp 336,9 } \\
\text { juta, batako Rp 366,4 juta dan bata ringan Rp 433,9 juta. } \\
\text { - } \text { Durasi pekerjaan dinding bata merah selama } 80 \text { hari, } \\
\text { btako } 67 \text { hari dan bata ringan } 74 \text { hari. }\end{array}$ \\
\hline 8 & \multicolumn{2}{|c|}{$\begin{array}{l}\text { Perbandingan Pelaksanaan } \\
\text { Dinding Precast dengan Dinding } \\
\text { Konvensional ditinjau dari segi } \\
\text { Waktu dan Biaya (Yulistianingsih } \\
\text { dan Trijeti (2014)) Jurnal } \\
\text { Konstruksia Vol. } 6\end{array}$} & $\begin{array}{l}\text { - Metode Analisa Harga Satuan SNI } 2011 \\
\text { - Pekerjaan dinding precast lebih mahal dengan selisih } \\
29 \% \text {, tetapi waktu pelaksanaanya jauh lebih cepat } \\
\text { bahkan mencapai angka 150\%. Sedangkan pekerjaan } \\
\text { dinding konvensional bata ringan lebih murah dari segi } \\
\text { biaya, tetapi waktu pelaksanaanya lebih lama. Dengan } \\
\text { kata lain pekerjaan dinding precast lebih efektif } \\
\text { dikerjakan tetapi kurang efisien dari segi biaya, apabila } \\
\text { bangunan yang dikerjakan dibawah } 10 \text { lantai. }\end{array}$ \\
\hline
\end{tabular}

Keterbaruan dari penelitian ini adalah dilakukannya perbandingan antara 4 material dinding dimana penelitian terdahulu pada umumnya membandingkan 2 material. Penelitian terdahulu hanya terbatas meneliti biaya dan waktu pelaksanaan, sedangkan penelitian ini melakukan penelitian terhadap karakteristik material berdasarkan tanggapan praktisi.

Harga dan kualitas merupakan dua hal yang selalu menjadi pertimbangan manusia dalam menentukan pilihan sehubungan dengan barang. Dibutuhkan data-data yang dapat menjadi pertimbangan bagi developer dan konsumen dalam menentukan material dinding, karenanya penelitian ini menetapkan empat material dinding yang cukup dikenal dan bahkan merupakan material konvensional yaitu bata, dan batako. Beton ringan termasuk material baru tetapi sudah cukup banyak digunakan utamanya pada bangunan tinggi, sedangkan M-Panel belum terlalu dikenal di Malang.

Dalam penelitian ini akan diteliti keuntungan dan kerugian dari material dinding bata, bata ringan, batako dan $\mathrm{m}$ panel yang meliputi karakteristik, biaya dan waktu pemasangan yang diharapkan akan dapat menjadi bahan pertimbangan dalam menentukan pilihan. 


\section{METODE PENELITIAN}

Obyek penelitian adalah topik yang menjadi permasalahan yang dikaji dalam penelitian, sedangkan subyek penelitian adalah narasumber yang menjadi sumber riset dalam penelitian (12). Objek dalam penelitian ini adalah material dinding komposit yaitu AAC, batako, M-Panel dan non-komposit yaitu bata. Subyek dalam penelitian adalah praktisi dalam bidang konstruksi yaitu kontraktor, konsultan dan developer.

Metode yang digunakan dalam melakukan pengambilan data (data collection) yaitu dengan melakukan:

1. Literatur review terhadap penelitian terdahulu, sebagaimana yang telah tercantum pada tabel di pendahuluan. Literatur review dilakukan untuk menemukan gap (celah) dalam penelitian.

2. Study literatur melalui internet, jurnal dan buku untuk menentukan karakteristik yang menjadi materi wawancara, sedangkan untuk biaya dan waktu didapatkan dari perhitungan dengan menggunakan AHSP Dirjen PU 2016 dengan rumus berikut.

Biaya $=$ Koefisien $\mathrm{x}$ Harga Satuan $\mathrm{x}$ Volume Pekerjaan

Sedangkan untuk perhitungan durasi, terlebih dahulu ditentukan jumlah tenaga yang akan digunakan dengan rumus berikut.

Tenaga $=\frac{\text { Koefisien } x \text { Volume Pekerjaan }}{\text { Jumlah Tenaga Tersedia }}$ Harga satuan yang digunakan berdasarkan harga satuan yang berlaku di kotamadya Malang pada tahun 2017.

Khusus untuk material M-Panel AHSP didapatkan dari website PT. Modern Panel Indonesia, sedangkan harganya berdasarkan

https://surayadimpanel.wordpress.com (2016) (13).

Wawancara terkait karakteristik material, dimana dalam wawancara diajukan 15 pertanyaan dan dijawab oleh responden dalam bentuk peringkat serta alasannya. Pertanyaan yang diajukan merujuk pada peringkat material dalam karakteristik tertentu sesuai opini responden. Karakteristik material diperoleh dari pendapat responden dimana responden diminta untuk:

1. Mengisi kolom [3] - [6] dengan angka 1 - 4 untuk menunjukkan tingkat/level, dimana angka 1 merupakan nilai tertinggi.

2. Mengisi kolom [7] dengan keterangan / penjelasan / alasan yang mendukung material tertentu sebagai pilihan tertinggi (angka 1).

3. Bentuk pertanyaan yang diajukan pada responden adalah sebagai berikut:

Tabel 2. Pertanyaan

\begin{tabular}{lllcccc}
\hline No. & Pertanyaan & & Material & & \multicolumn{1}{c}{$\begin{array}{c}\text { Keterangan/ } \\
\text { Penjelasan/Alasan }\end{array}$} \\
\cline { 3 - 6 } & & & & & \\
\cline { 3 - 6 } & & & Bata & Batako AAC & M-Panel & \\
\hline$[1]$ & {$[2]$} & {$[3]$} & {$[4]$} & {$[5]$} & {$[6]$} & {$[7]$} \\
\hline 1 & $\begin{array}{l}\text { Peringkat frekwensi pemakaian material } \\
\text { dalam proyek ?. }\end{array}$ & & & & & \\
\hline 2 & $\begin{array}{l}\text { Peringkat biaya pelaksanaan material } \\
\text { sebagai konstruksi dinding ?. }\end{array}$ & & & & \\
\hline
\end{tabular}




\begin{tabular}{|c|c|c|c|c|c|}
\hline \multirow[t]{2}{*}{ No. } & \multirow[t]{2}{*}{ Pertanyaan } & \multicolumn{3}{|c|}{ Material } & \multirow{2}{*}{$\begin{array}{c}\text { Keterangan/ } \\
\text { Penjelasan/Alasan }\end{array}$} \\
\hline & & $\overline{\text { Bata }}$ & Batako AAC & M-Panel & \\
\hline$[1]$ & [2] & [3] & {$[5]$} & {$[6]$} & [7] \\
\hline 3 & $\begin{array}{l}\text { Peringkat lama waktu pelaksanaan } \\
\text { material sebagai konstruksi dinding?. }\end{array}$ & & & & \\
\hline 4 & $\begin{array}{l}\text { Peringkat luasan area yang dibutuhkan } \\
\text { untuk penyimpanan material ?. }\end{array}$ & & & & \\
\hline 5 & $\begin{array}{l}\text { Peringkat ketersediaan material di } \\
\text { Malang?. }\end{array}$ & & & & \\
\hline 6 & $\begin{array}{l}\text { Peringkat kemampuan aplikasi material } \\
\text { pada rumah bertingkat?. }\end{array}$ & & & & \\
\hline 7 & $\begin{array}{l}\text { Peringkat adaptasi/penyesuaian material } \\
\text { terhadap kebutuhan } \\
\text { dimensi/desain/ruang?. }\end{array}$ & & & & \\
\hline 8 & $\begin{array}{l}\text { Peringkat ketahanan material sebagai } \\
\text { konstruksi dinding terhadap } \\
\text { kelembaban?. }\end{array}$ & & & & \\
\hline 9 & $\begin{array}{l}\text { Peringkat keawetan/durabilitas material } \\
\text { sebagai konstruksi dinding?. }\end{array}$ & & & & \\
\hline 10 & $\begin{array}{l}\text { Peringkat kemampuan material sebagai } \\
\text { material Re-Use?. }\end{array}$ & & & & \\
\hline 11 & $\begin{array}{l}\text { Peringkat kemampuan material sebagai } \\
\text { material Re-Cycle?. }\end{array}$ & & & & \\
\hline 12 & $\begin{array}{l}\text { Peringkat pencemaran udara pada saat } \\
\text { aplikasi material sebagai konstruksi } \\
\text { dinding?. }\end{array}$ & & & & \\
\hline 13 & $\begin{array}{l}\text { Peringkat pencemaran air pada saat } \\
\text { aplikasi material sebagai konstruksi } \\
\text { dinding?. }\end{array}$ & & & & \\
\hline 14 & $\begin{array}{l}\text { Peringkat pencemaran tanah pada saat } \\
\text { aplikasi material sebagai konstruksi } \\
\text { dinding?. }\end{array}$ & & & & \\
\hline 15 & Peringkat berat material ?. & & & & \\
\hline
\end{tabular}

Catatan:

1. Peringkat frekwensi pemakaian material dalam proyek ?. (tertinggi = terbanyak pemakaian)

2. Peringkat biaya pelaksanaan material sebagai konstruksi dinding ?. (tertinggi $=$ terbesar biaya pelaksanaan)

3. Peringkat lama waktu pelaksanaan material sebagai konstruksi dinding ?. (tertinggi = terlama waktu pelaksanaan)

4. Peringkat luasan area yang dibutuhkan untuk penyimpanan material ?. (tertinggi $=$ terluas)

5. Peringkat ketersediaan material di Malang ? (tertinggi $=$ terbanyak tersedia)
6. Peringkat kemampuan aplikasi material pada rumah bertingkat ?. (tertinggi = ter-mampu dijadikan dinding rumah bertingkat)

7. Peringkat adaptasi/penyesuaian material terhadap kebutuhan dimensi/desain/ruang ?. (tertinggi $=$ ter-mampu disesuaikan dengan kebutuhan desain)

8. Peringkat ketahanan material sebagai konstruksi dinding terhadap kelembaban ?. (tertingi $=$ terkuat terhadap menahan kelembaban)

9. Peringkat keawetan/durabilitas material sebagai konstruksi dinding ?. (tertinggi = terawet) 
10. Peringkat kemampuan material sebagai material Re-Use ?. (tertinggi = ter-mampu)

11. Peringkat kemampuan material sebagai material Re-Cycle ?. (tertinggi = ter-mampu)

12. Peringkat pencemaran udara pada saat aplikasi material sebagai konstruksi dinding ?. (tertinggi $=$ tertinggi tingkat pencemaran)

13. Peringkat pencemaran air pada saat aplikasi material sebagai konstruksi dinding ?. (tertinggi $=$ tertinggi tingkat pencemaran)

14. Peringkat pencemaran tanah pada saat aplikasi material sebagai konstruksi dinding ?. (tertinggi $=$ tertinggi tingkat pencemaran)
15. Peringkat berat material ?. (tertinggi = terberat)

\section{HASIL DAN PEMBAHASAN}

Penelitian ini bertujuan untuk mengetahui karakteristik, biaya dan durasi dari aplikasi material dinding yang berbeda. Material diaplikasikan pada rumah tipe 38 yang tergolong sebagai tipe rumah sederhana. Denah rumah diambil dari Mutiara Jingga Regency (Malang) sebagaimana yang tercantum pada gambar berikut dengan luas dinding 111,125 $\mathrm{m}^{2}$.

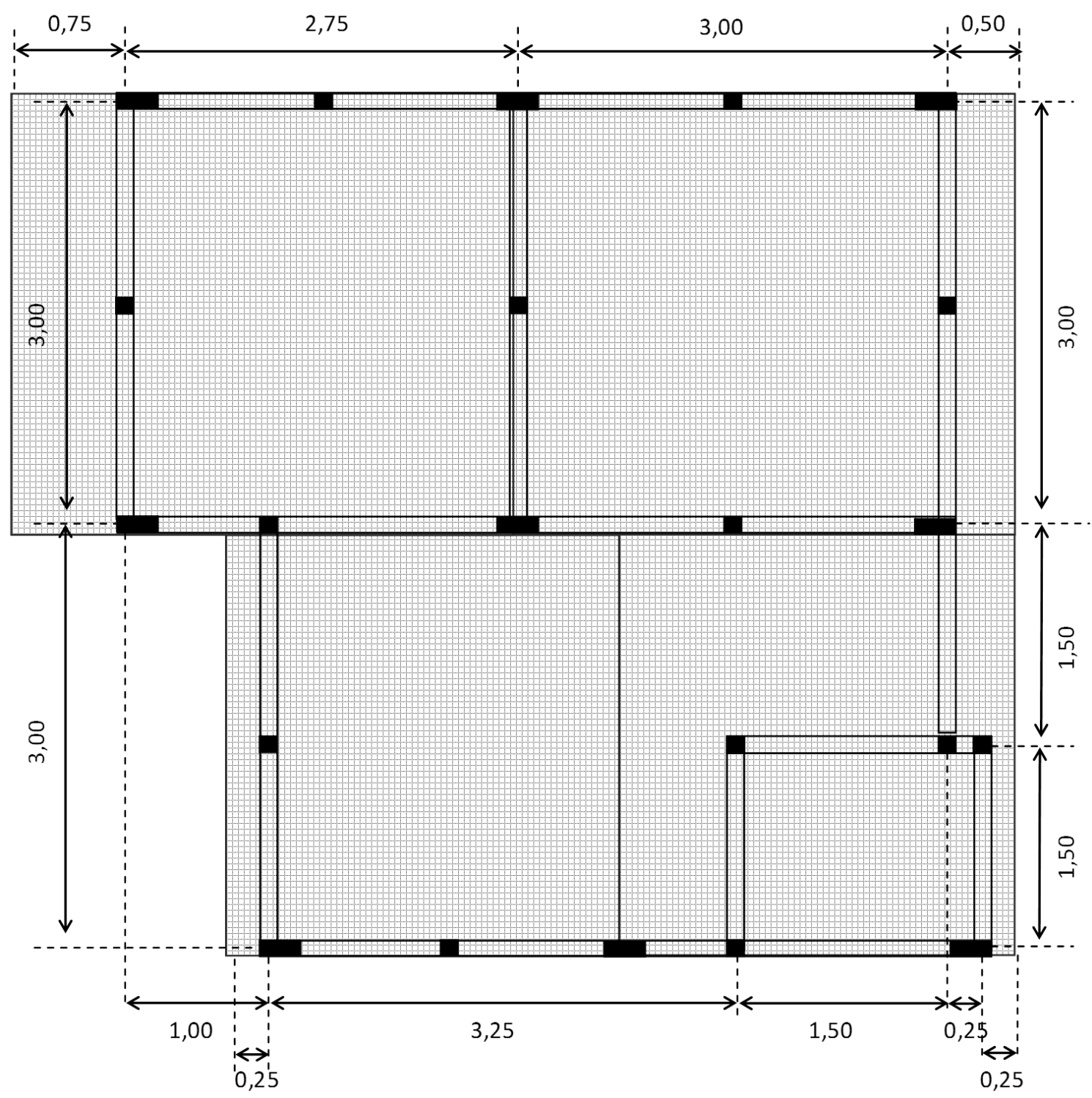

Gambar 1. Denah Rumah Tipe 38 Mutiara Jingga Regency 


\subsection{DINDING BATA}

Tabel 3. Pemasangan $1 \mathrm{~m}^{2}$ Dinding Bata Merah $(5 \times 11 \times 22) \mathrm{cm}$, Tebal $1 / 2$ batu,

Campuran 1 SP : 2 PP

\begin{tabular}{|c|c|c|c|c|c|c|c|c|c|}
\hline No. & Uraian & Satuan & Koef & \multicolumn{2}{|c|}{ Harga Satuan } & \multicolumn{2}{|r|}{ Biaya } & $\sum$ Tenaga & Durasi (hr) \\
\hline \multirow[t]{5}{*}{$\mathrm{A}$} & Tenaga & & & & & & & & \\
\hline & Pekerja & $\mathrm{OH}$ & 0,3 & $\mathrm{Rp}$ & 50.000 & $\mathrm{Rp}$ & 1.461 .900 & 29,2 & 9,7 \\
\hline & Tukang Batu & $\mathrm{OH}$ & 0,1 & $\mathrm{Rp}$ & 65.000 & $\mathrm{Rp}$ & 633.490 & 9,7 & 4,9 \\
\hline & Kepala Tukang & $\mathrm{OH}$ & 0,01 & $\mathrm{Rp}$ & 80.000 & $\mathrm{Rp}$ & 77.968 & 1,0 & 1,0 \\
\hline & Mandor & $\mathrm{OH}$ & 0,015 & $\mathrm{Rp}$ & 100.000 & $\mathrm{Rp}$ & 146.190 & 1,5 & 1,5 \\
\hline \multirow[t]{5}{*}{ B } & Bahan & & & & & & & & \\
\hline & Bata Merah & buah & 70 & $\mathrm{Rp}$ & 600 & $\mathrm{Rp}$ & 4.093 .320 & & \\
\hline & Semen Portland & $\mathrm{kg}$ & 18,95 & $\mathrm{Rp}$ & 1.350 & $\mathrm{Rp}$ & 2.493 .270 & & \\
\hline & Pasir Pasang & $\mathrm{m}^{3}$ & 0,038 & $\mathrm{Rp}$ & 132.000 & $\mathrm{Rp}$ & 488.859 & & \\
\hline & & & & & & $\mathrm{Rp}$ & 9.394 .998 & & \\
\hline
\end{tabular}

Tabel 4. Pemasangan $1 \mathrm{~m}^{2}$ Plesteran 1SP : 1PP, Tebal $15 \mathrm{~mm}$

\begin{tabular}{|c|c|c|c|c|c|c|c|c|c|}
\hline No. & Uraian & Satuan & Koef & \multicolumn{2}{|c|}{ Harga Satuan } & \multicolumn{2}{|r|}{ Biaya } & $\Sigma$ Tenaga & Durasi (hr) \\
\hline \multirow[t]{5}{*}{ A } & Tenaga & & & & & & & & \\
\hline & Pekerja & $\mathrm{OH}$ & 0,3 & $\mathrm{Rp}$ & 50.000 & $\mathrm{Rp}$ & 1.461 .900 & 29,2 & 9,7 \\
\hline & Tukang Batu & $\mathrm{OH}$ & 0,15 & $\mathrm{Rp}$ & 65.000 & $\mathrm{Rp}$ & 950.235 & 14,6 & 7,3 \\
\hline & Kepala Tukang & $\mathrm{OH}$ & 0,015 & $\mathrm{Rp}$ & 80.000 & $\mathrm{Rp}$ & 116.952 & 1,5 & 1,5 \\
\hline & Mandor & $\mathrm{OH}$ & 0,015 & $\mathrm{Rp}$ & 100.000 & $\mathrm{Rp}$ & 146.190 & 1,5 & 1,5 \\
\hline \multirow[t]{4}{*}{$\mathrm{B}$} & Bahan & & & & & & & & \\
\hline & Semen Portland & $\mathrm{kg}$ & 15,504 & $\mathrm{Rp}$ & 1.350 & $\mathrm{Rp}$ & 2.039 .877 & & \\
\hline & Pasir Pasang & $\mathrm{m}^{3}$ & 0,016 & $\mathrm{Rp}$ & 132.000 & $\mathrm{Rp}$ & 205.836 & & \\
\hline & & & & & & $\mathrm{Rp}$ & 4.920 .989 & & \\
\hline
\end{tabular}

Tabel 5. Pemasangan $1 \mathrm{~m}^{2}$ Acian

\begin{tabular}{|c|c|c|c|c|c|c|c|c|c|}
\hline No. & Uraian & Satuan & Koef & \multicolumn{2}{|c|}{ Harga Satuan } & \multicolumn{2}{|r|}{ Biaya } & $\Sigma$ Tenaga & Durasi (hr) \\
\hline \multirow[t]{5}{*}{ A } & Tenaga & & & & & & & & \\
\hline & Pekerja & $\mathrm{OH}$ & 0,2 & $\mathrm{Rp}$ & 50.000 & $\mathrm{Rp}$ & 974.600 & 19,5 & 6,5 \\
\hline & Tukang Batu & $\mathrm{OH}$ & 0,1 & $\mathrm{Rp}$ & 65.000 & $\mathrm{Rp}$ & 633.490 & 9,7 & 4,9 \\
\hline & Kepala Tukang & $\mathrm{OH}$ & 0,01 & $\mathrm{Rp}$ & 80.000 & $\mathrm{Rp}$ & 77.968 & 1,0 & 1,0 \\
\hline & Mandor & $\mathrm{OH}$ & 0,01 & $\mathrm{Rp}$ & 100.000 & $\mathrm{Rp}$ & 97.460 & 1,0 & 1,0 \\
\hline \multirow[t]{3}{*}{ B } & Bahan & & & & & & & & \\
\hline & Semen Portland & $\mathrm{kg}$ & 3,25 & $\mathrm{Rp}$ & 1.350 & $\mathrm{Rp}$ & 427.606 & & \\
\hline & & & & & & $\mathrm{Rp}$ & 2.211 .124 & & \\
\hline
\end{tabular}

Rekapitulasi biaya pelaksanaan dinding bata:

Rp 9.394.998 + Rp 4.920.989 + Rp 2.211.124 = Rp 16.527.111,-

Rekapitulasi durasi pelaksanaan dinding bata:

$9,7+9,7+6,5=26$ hari

\subsection{DINDING BATA RINGAN (AAC)}

Tabel 6. Pemasangan 1m2 Dinding Bata Ringan 60x10x20, Tebal $10 \mathrm{~cm}$ dengan MSP

\begin{tabular}{|c|c|c|c|c|c|c|c|c|c|}
\hline No. & Uraian & Satuan & Koef & \multicolumn{2}{|c|}{ Harga Satuan } & \multicolumn{2}{|r|}{ Biaya } & $\sum$ Tenaga & Durasi (hr) \\
\hline $\mathrm{A}$ & Tenaga & & & & & & & & \\
\hline & Pekerja & $\mathrm{OH}$ & 0,272 & $\mathrm{Rp}$ & 50.000 & $\mathrm{Rp}$ & 1.325 .456 & 26,5 & 8,8 \\
\hline & Tukang Batu & $\mathrm{OH}$ & 0,085 & $\mathrm{Rp}$ & 65.000 & $\mathrm{Rp}$ & 538.467 & 8,3 & 4,1 \\
\hline & Kepala Tukang & $\mathrm{OH}$ & 0,009 & $\mathrm{Rp}$ & 80.000 & $\mathrm{Rp}$ & 70.171 & 0,9 & 0,9 \\
\hline & Mandor & $\mathrm{OH}$ & 0,013 & $\mathrm{Rp}$ & 100.000 & $\mathrm{Rp}$ & 126.698 & 12,7 & 12,7 \\
\hline
\end{tabular}




\begin{tabular}{|c|c|c|c|c|c|c|}
\hline B & Bahan & & & & & \\
\hline & $\begin{array}{l}\text { Bata Ringan } \\
\text { Tebal } 10 \mathrm{~cm}\end{array}$ & buah & 8,4 & $\mathrm{Rp}$ & 10.000 & Rp 8.186 .640 \\
\hline & MSP MU-380 & $\mathrm{kg}$ & 0,063 & $\mathrm{Rp}$ & 3.125 & 19.187 \\
\hline & & & & & & Rp10.266.619 \\
\hline
\end{tabular}

Tabel 7. Pemasangan $1 \mathrm{~m} 2$ Plesteran dengan MSP

\begin{tabular}{clcccccccc}
\hline No. & \multicolumn{1}{c}{ Uraian } & Satuan & Koef & Harga Satuan & & Biaya & $\sum$ Tenaga & Durasi (hr) \\
\hline A & Tenaga & & & & & & & & \\
\hline & Pekerja & $\mathrm{OH}$ & 0,2 & $\mathrm{Rp}$ & 50.000 & $\mathrm{Rp}$ & 974.600 & 19,5 & 6,5 \\
\hline & Tukang Batu & $\mathrm{OH}$ & 0,15 & $\mathrm{Rp}$ & 65.000 & $\mathrm{Rp}$ & 950.235 & 14,6 & 7,3 \\
\hline Kepala Tukang & $\mathrm{OH}$ & 0,015 & $\mathrm{Rp}$ & 80.000 & $\mathrm{Rp}$ & 116.952 & 1,5 & 1,5 \\
\hline & Mandor & $\mathrm{OH}$ & 0,01 & $\mathrm{Rp}$ & 100.000 & $\mathrm{Rp}$ & 97.460 & 1,0 & 1,0 \\
\hline $\mathrm{B}$ & Bahan & $\mathrm{kg}$ & 16,67 & $\mathrm{Rp}$ & 1.500 & $\mathrm{Rp}$ & 2.436 .987 \\
\hline & MSP MU-301 & & & & & $\mathrm{Rp}$ & 4.576 .234 \\
\hline
\end{tabular}

Tabel 8. Pemasangan $1 \mathrm{~m} 2$ Acian dengan MSP

\begin{tabular}{|c|c|c|c|c|c|c|c|c|c|}
\hline No. & Uraian & Satuan & Koef & \multicolumn{2}{|c|}{ Harga Satuan } & \multicolumn{2}{|r|}{ Biaya } & $\Sigma$ Tenaga & Durasi (hr) \\
\hline \multirow[t]{5}{*}{ A } & Tenaga & & & & & & & & \\
\hline & Pekerja & $\mathrm{OH}$ & 0,143 & $\mathrm{Rp}$ & 50.000 & $\mathrm{Rp}$ & 696.839 & 13,9 & 4,6 \\
\hline & Tukang Batu & $\mathrm{OH}$ & 0,107 & $\mathrm{Rp}$ & 65.000 & $\mathrm{Rp}$ & 677.834 & 10,4 & 5,2 \\
\hline & Kepala Tukang & $\mathrm{OH}$ & 0,011 & $\mathrm{Rp}$ & 80.000 & $\mathrm{Rp}$ & 85.765 & 1,1 & 1,1 \\
\hline & Mandor & $\mathrm{OH}$ & 0,011 & $\mathrm{Rp}$ & 100.000 & $\mathrm{Rp}$ & 107.206 & 1,1 & 1,1 \\
\hline \multirow[t]{3}{*}{$\mathrm{B}$} & Bahan & & & & & & & & \\
\hline & MSP MU-270 & $\mathrm{kg}$ & 2 & $\mathrm{Rp}$ & 6.342 & $\mathrm{Rp}$ & 1.236 .183 & & \\
\hline & & & & & & $\mathrm{Rp}$ & 2.803 .827 & & \\
\hline
\end{tabular}

Rekapitulasi biaya pelaksanaan dinding bata ringan:

$\mathrm{Rp}$ 10.266.619 + Rp 4.576.234 + Rp 2.803.827 = Rp 17.646.680,-

Rekapitulasi durasi pelaksanaan dinding bata ringan:

$8,8+7,3+5,2=21,4$ hari

\subsection{DINDING BATAKO}

Tabel 9. Pemasangan 1m2 Dinding Conblock HB-15 Campuran 1SP : 3PP

\begin{tabular}{|c|c|c|c|c|c|c|c|c|c|}
\hline No. & Uraian & Satuan & Koef & \multicolumn{2}{|c|}{ Harga Satuan } & \multicolumn{2}{|r|}{ Biaya } & $\Sigma$ Tenaga & Durasi (hr) \\
\hline \multirow[t]{5}{*}{ A } & Tenaga & & & & & & & & \\
\hline & Pekerja & $\mathrm{OH}$ & 0,32 & $\mathrm{Rp}$ & 50.000 & $\mathrm{Rp}$ & 1.559 .360 & 31,2 & 10,4 \\
\hline & Tukang Batu & $\mathrm{OH}$ & 0,12 & $\mathrm{Rp}$ & 65.000 & $\mathrm{Rp}$ & 760.188 & 11,7 & 5,8 \\
\hline & Kepala Tukang & $\mathrm{OH}$ & 0,012 & $\mathrm{Rp}$ & 80.000 & $\mathrm{Rp}$ & 93.562 & 1,2 & 1,2 \\
\hline & Mandor & $\mathrm{OH}$ & 0,016 & $\mathrm{Rp}$ & 100.000 & $\mathrm{Rp}$ & 155.936 & 1,6 & 1,6 \\
\hline \multirow[t]{6}{*}{ B } & Bahan & & & & & & & & \\
\hline & HB-15 & buah & 12,5 & $\mathrm{Rp}$ & 4.500 & $\mathrm{Rp}$ & 5.482 .125 & & \\
\hline & Semen Portland & $\mathrm{kg}$ & 6,25 & $\mathrm{Rp}$ & 1.350 & $\mathrm{Rp}$ & 822.319 & & \\
\hline & Pasir Pasang & $\mathrm{m}^{3}$ & 0,015 & $\mathrm{Rp}$ & 132.000 & $\mathrm{Rp}$ & 192.971 & & \\
\hline & $\begin{array}{l}\text { Besi Angker } \phi 8 \\
\text { mm }\end{array}$ & $\mathrm{kg}$ & 0,28 & $\mathrm{Rp}$ & 13.950 & $\mathrm{Rp}$ & 380.679 & & \\
\hline & & & & & & $\mathrm{Rp}$ & 9.447 .139 & & \\
\hline
\end{tabular}

Untuk plesteran dan acian ditentukan menggunakan komposisi yang sama dengan pasangan bata, sehingga perhitungan biaya dan durasi menggunakan data yang sama.

Rekapitulasi biaya pelaksanaan dinding batako: 
Rp 9.447.139 + Rp 4.920.989 + Rp 2.211.124 = Rp 16.579.252,-

Rekapitulasi durasi pelaksanaan dinding batako:

$10,4+9,7+6,5=26,6$ hari

\subsection{DINDING M-PANEL}

Tabel 10. Pemasangan $1 \mathrm{~m} 2$ Dinding M-Panel PSM 8

\begin{tabular}{|c|c|c|c|c|c|c|c|c|c|}
\hline \multirow{2}{*}{ No. } & \multirow{2}{*}{$\frac{\text { Uraian }}{\text { Tenaga }}$} & \multirow[t]{2}{*}{ Satuan } & \multirow[t]{2}{*}{ Koef } & \multicolumn{2}{|c|}{ Harga Satuan } & \multicolumn{2}{|c|}{ Biaya } & \multirow{2}{*}{$\Sigma$ Tenaga } & \multirow[t]{2}{*}{ Durasi (hr) } \\
\hline & & & & & & & & & \\
\hline & Pekerja & $\mathrm{OH}$ & 0,04 & $\mathrm{Rp}$ & 50.000 & $\mathrm{Rp}$ & 194.920 & 3,9 & 1,3 \\
\hline & Tukang Batu & $\mathrm{OH}$ & 0,08 & $\mathrm{Rp}$ & 65.000 & $\mathrm{Rp}$ & 506.792 & 7,8 & 3,9 \\
\hline & Mandor & $\mathrm{OH}$ & 0,01 & $\mathrm{Rp}$ & 100.000 & $\mathrm{Rp}$ & 97.460 & 1,0 & 1,0 \\
\hline B & Bahan & & & & & & & & \\
\hline & $\begin{array}{l}\text { Dinding M- } \\
\text { Panel }(10 \mathrm{~cm})\end{array}$ & $\mathrm{m}^{2}$ & 1 & Rp & 254.700 & & 823.062 & & \\
\hline & $\begin{array}{l}\text { Besi Polos } \phi 8 \\
\text { mm }\end{array}$ & $\mathrm{kg}$ & 0,47 & $\mathrm{Rp}$ & 13.950 & $\mathrm{Rp}$ & 638.996 & & \\
\hline & & & & & & $\mathrm{Rp} 2$ & 261.230 & & \\
\hline
\end{tabular}

Tabel 11. Pemasangan $1 \mathrm{~m} 2$ Plesteran Dinding Tahap I

\begin{tabular}{|c|c|c|c|c|c|c|c|c|c|}
\hline \multirow{2}{*}{$\begin{array}{c}\text { No. } \\
\text { A }\end{array}$} & \multirow{2}{*}{$\begin{array}{l}\text { Uraian } \\
\text { Tenaga }\end{array}$} & \multirow[t]{2}{*}{ Satuan } & \multirow[t]{2}{*}{ Koef } & \multicolumn{2}{|c|}{ Harga Satuan } & \multicolumn{2}{|c|}{ Biaya } & \multirow{2}{*}{$\sum$ Tenaga } & \multirow[t]{2}{*}{ Durasi (hr) } \\
\hline & & & & & & & & & \\
\hline & $\begin{array}{l}\text { Tukang } \\
\text { Semprot Plester }\end{array}$ & $\mathrm{OH}$ & 0,0009 & $\mathrm{Rp}$ & 60.000 & $\mathrm{Rp}$ & 5.263 & 0,09 & 0,09 \\
\hline & Operator & $\mathrm{OH}$ & 0,0009 & $\mathrm{Rp}$ & 75.000 & $\mathrm{Rp}$ & 6.579 & 0,09 & 0,09 \\
\hline & Mandor & $\mathrm{OH}$ & 0,0001 & $\mathrm{Rp}$ & 100.000 & $\mathrm{Rp}$ & 975 & 0,01 & 0,01 \\
\hline & Turbosol & hari & 0,002 & $\mathrm{Rp}$ & 2.500 .000 & $\mathrm{Rp}$ & 487.300 & & \\
\hline & Molen & hari & 0,002 & $\mathrm{Rp}$ & 295.000 & $\mathrm{Rp}$ & 57.501 & & \\
\hline B & Bahan & & & & & & & & \\
\hline & Semen & $\mathrm{kg}$ & 14,56 & $\mathrm{Rp}$ & 1.350 & $\mathrm{Rp}$ & 1.915 .674 & & \\
\hline & Pasir Pasang & $\mathrm{m}^{3}$ & 0,056 & $\mathrm{Rp}$ & 132.000 & $\mathrm{Rp}$ & 720.424 & & \\
\hline & & & & & & $\mathrm{Rp}$ & 3.193 .715 & & \\
\hline
\end{tabular}

Tabel 12. Pemasangan $1 \mathrm{~m} 2$ Plesteran Dinding Tahap II

\begin{tabular}{|c|c|c|c|c|c|c|c|c|c|}
\hline \multirow{2}{*}{$\frac{\text { No. }}{A}$} & Uraian & Satuan & Koef & \multicolumn{2}{|c|}{ Harga Satuan } & \multicolumn{2}{|c|}{ Biaya } & $\sum$ Tenaga & \multirow[t]{2}{*}{ Durasi (hr) } \\
\hline & Tenaga & & & & & & & & \\
\hline & $\begin{array}{l}\text { Tukang } \\
\text { Semprot Plester }\end{array}$ & $\mathrm{OH}$ & 0,004 & $\mathrm{Rp}$ & 60.000 & $\mathrm{Rp}$ & 23.390 & 0,4 & 0,4 \\
\hline & Operator & $\mathrm{OH}$ & 0,004 & $\mathrm{Rp}$ & 75.000 & $\mathrm{Rp}$ & 29.238 & 0,4 & 0,4 \\
\hline & Mandor & $\mathrm{OH}$ & 0,0004 & $\mathrm{Rp}$ & 80.000 & $\mathrm{Rp}$ & 3.119 & 0,0 & 0,0 \\
\hline & Turbosol & hari & 0,007 & $\mathrm{Rp}$ & .500 .000 & $\mathrm{Rp}$ & 1.023 .330 & & \\
\hline & Molen & hari & 0,007 & $\mathrm{Rp}$ & 295.000 & $\mathrm{Rp}$ & 201.255 & & \\
\hline $\mathrm{B}$ & Bahan & & & & & & & & \\
\hline & Semen & $\mathrm{kg}$ & 14,56 & $\mathrm{Rp}$ & 1.350 & $\mathrm{Rp}$ & 1.915 .674 & & \\
\hline & Pasir & $\mathrm{m}^{3}$ & 0,056 & $\mathrm{Rp}$ & 132.000 & $\mathrm{Rp}$ & 720.424 & & \\
\hline & & & & & & $\mathrm{Rp}$ & 3.916 .430 & & \\
\hline
\end{tabular}

Rekapitulasi biaya pelaksanaan dinding M-Panel:

Rp 26.261.230 + Rp 3.193.715 + Rp 3.916.430 = Rp 33.371.376,-

Rekapitulasi durasi pelaksanaan dinding M-Panel:

$3,9+0,09+0,4=4,4$ hari 


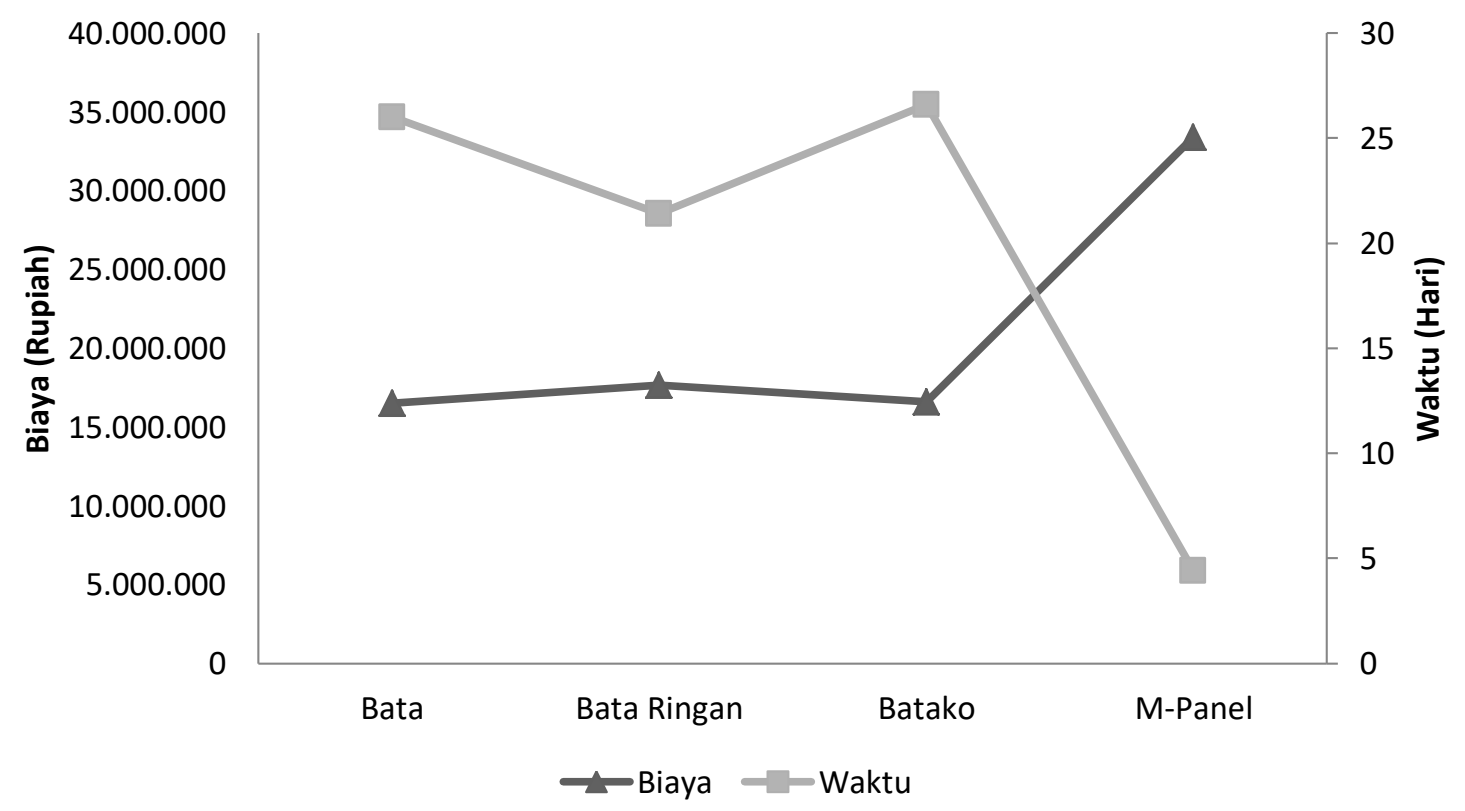

Gambar 2. Perbandingan Biaya dan Waktu Pelaksanaan

\subsection{KARAKTERISTIK}

Tabel 13. Nilai Mode dari Hasil Wawancara

\begin{tabular}{ccccc}
\hline \multirow{2}{*}{ Pertanyaan } & \multicolumn{4}{c}{ Mode } \\
\cline { 2 - 5 } & Bata & Batako & AAC & M-Panel \\
\hline 1 & 1 & 2 & 3 & 4 \\
\hline 2 & 4 & 3 & 2 & 1 \\
\hline 3 & 1 & 2 & 3 & 4 \\
\hline 4 & 4 & 2 & 3 & 1 \\
\hline 5 & 1 & 2 & 3 & 4 \\
\hline 6 & 1 & 4 & 2 & 3 \\
\hline 7 & 1 & 4 & 2 & 4 \\
\hline 8 & 1 & 2 & 2 & 4 \\
\hline 9 & 1 & 4 & 2 & 1 \\
\hline 10 & 1 & 2 & 3 & 4 \\
\hline 11 & 1 & 2 & 3 & 4 \\
\hline 12 & 4 & 2 & 1 & 4 \\
\hline 13 & 1 & 3 & 2 & 4 \\
\hline 14 & 1 & 2 & 3 & 4 \\
\hline 15 & 2 & 1 & 3 & 4 \\
\hline
\end{tabular}

Berdasarkan hasil dari tabel Nilai Mode tersebut dengan menginterpretasikan peringkat 1 = sangat, 2 = banyak / tinggi / mudah / mampu / berat, $3=$ cukup, $4=$ tidak, maka perbandingan karakteristik terhadap tiap - tiap material sebagai berikut: 1. Bata
- Sangat banyak digunakan di kota Malang.

- Biaya pelaksanaan tidak tinggi.

- Waktu pelaksanaan sangat lama.

- Membutuhkan area penyimpanan yang tidak luas.

- Sangat banyak tersedia. 
- Sangat mudah diaplikasikan pada rumah bertingkat.

- Sangat mudah disesuaikan dengan kebutuhan desain/ruang.

- Sangat tahan terhadap kelembaban.

- Sangat awet.

- Sangat mampu untuk digunakan kembali (Re-Use).

- Sangat mampu untuk didaur ulang (Re-Cycle).

- Pencemaran udara tidak tinggi.

- Pencemaran air sangat tinggi.

- Pencemaran tanah sangat tinggi.

- Material berat.

2. Batako

- Banyak digunakan di kota Malang.

- Biaya pelaksanaan tidak terlalu tinggi.

- Waktu pelaksanaan lama.

- Membutuhkan area penyimpanan yang luas.

- Banyak tersedia.

- Tidak mudah atau sulit diaplikasikan pada rumah bertingkat.

- Tidak mudah atau sulit disesuaikan dengan kebutuhan desain/ruang.

- Tahan terhadap kelembaban.

- Tidak awet.

- Mampu untuk digunakan kembali (ReUse).

- Mampu untuk didaur ulang (ReCycle).

- Pencemaran udara tinggi.

- Pencemaran air cukup tinggi.

- Pencemaran tanah tinggi.

- Material sangat berat.

3. Bata Ringan (AAC)

- Cukup banyak digunakan di kota Malang.

- Biaya pelaksanaan tinggi.

- Waktu tidak terlalu lama.
- Membutuhkan area penyimpanan yang tidak terlalu luas.

- Cukup banyak tersedia.

- Mudah diaplikasikan pada rumah bertingkat.

- Mudah disesuaikan dengan kebutuhan desain/ruang.

- Tahan terhadap kelembaban.

- Awet.

- Cukup mampu untuk digunakan kembali (Re-Use).

- Cukup mampu untuk didaur ulang (Re-Cycle).

- Pencemaran udara sangat tinggi.

- Pencemaran air tinggi.

- Pencemaran tanah cukup tinggi.

- Material cukup berat.

4. M-Panel

- Tidak banyak digunakan di kota Malang.

- Biaya pelaksanaan sangat tinggi.

- Waktu tidak lama.

- Membutuhkan area penyimpanan yang sangat luas.

- Tidak banyak tersedia.

- Cukup mudah diaplikasikan pada rumah bertingkat.

- Tidak mudah disesuaikan dengan kebutuhan desain/ruang.

- Tidak tahan terhadap kelembaban.

- Sangat awet.

- Tidak mampu untuk digunakan kembali (Re-Use).

- Tidak mampu untuk didaur ulang (ReCycle).

- Pencemaran udara tidak tinggi.

- Pencemaran air tidak tinggi.

- Pencemaran tanah tidak tinggi.

- Material tidak berat. 


\section{KESIMPULAN}

1. Biaya pelaksanaan tertinggi didapatkan dari hasil perhitungan konstruksi dinding M-Panel, sedangkan biaya terendah adalah dinding conblok/batako.

2. Waktu pelaksanaan tercepat didapatkan dari hasil perhitungan konstruksi M-Panel sedangkan waktu terlama adalah dinding conblok/batako.

3. Grafik perbandingan biaya dan waktu memberikan hasil kontradiksi antara biaya dan waktu, dimana biaya berbanding terbalik dengan waktu pelaksanaan, artinya walaupun biaya pelaksanaan cenderung tinggi tetapi waktu pelaksanaannya relatif cepat.

4. Waktu untuk penyebaran kuesioner menjadi salah satu aspek yang harus direncanakan dalam proses pengumpulan data, utamanya terkait dengan responden praktisi yang bersifat dinamis dengan mobilitas tinggi.

\section{PENGHARGAAN}

Penulis mengucapkan terimakasih kepada Ditjen DIKTI yang telah mendanai penelitian ini di dalam skema Penelitian Dosen Pemula 2017. Pada kesempatan ini, penulis juga ingin mengucapkan terimakasih kepada keluarga dan seluruh pihak yang telah memberikan dukungan sehingga penelitian ini dapat terlaksana dengan baik. Secara khusus, Penulis menyampaikan terima kasih kepada:

1. Ibu Nindya Santi (CV. Arraafidan)

2. Bapak Sugeng Cahyo Purnomo (PT. Morse)

3. Bapak Sugeng Rahardjo (CV. Trimitra Lexata)

\section{DAFTAR PUSTAKA}

1. Manto, J. Mengidentifikasi Durasi dan Tenaga Kerja berdasarkan Analisa Harga Satuan Pekerjaan (AHSP) pada Perencanaan Villa Damai. Gorontalo : Sekolah Tinggi Teknik Bina Taruna, 2012.

2. Admin. http://architectaria.com/. [Online] 2012. [Dikutip: 17 Agustus 2018.]

3. hebelindonesia. hebelindonesia.com. [Online] 2013. [Dikutip: 8 Desember 2015.]

4. MPI. http://mpanelindonesia.com/. [Online] 2015. [Dikutip: 14 Mei 2018.]

5. Analisa Produktivitas Pemasangan Dinding dengan Material M-Panel. Akbar, M. Ilham. 2014, Student Journal.

6. Analisis Perbandingan Waktu dan Biaya dalam Penggunaan Bata Merah dengan M-Panel . Purwanti, Heny. 2014, Jurnal Teknologi, Vol. 2.

7. Analisis Perbandingan Biaya Dan Waktu Pekerjaan Dinding Menggunakan Bata Merah Dengan M-Panel. Dharmayanti, G.A.P Candra, Sudipta, I Gusti Ketut dan Saputra, Gede Tusan. 2016, Jurnal Ilmiah Teknik Sipil, Vol. 20.

8. Perbitungan Harga Satuan Pekerjaan Dinding Bata Ringan dengan Metode SNI dan Ms Project pada Proyek Pembangunan Gedung Laboratorium Enterpreneurship Terpadu Universitas Brawijaya Malang. Unas, Saifoe E1, Hasyim, Hamzah dan Aditha, Marchel. 2015, Jurnal Rekayasa Sipil, Vol. 9.

9. Analisa Produktivitas Pekerjaan Dinding Panel, Dinding Batu Bata Konvensional, dan SNI Pekerjaan Dinding . Unas, Saifoe El, N, Kartika Puspa dan P.Y, Rifky Rezha. 2015, Student Journal, Vol. 1.

10. Analisa Produktifitas Dinding Bata Ringan dan Dinding Precast pada Bangunan Gedung Tinggi Hunian. Kristiana, Retna dan Pujiandi, Aan. 2, 2016, Rekayasa Sipil, Vol. 5, hal. 81-92.

11. Analisa Perbandingan Estimasi Biaya dan Waktu pada Pekerjaan Dinding Bata Merah, Batako, dan Bata Ringan pada Gedung. Fairuzz, Gusti Reza. 2018, SPMI Poltekba.

12. Admin. http://sosiologis.com/. [Online] 3 Agustus 2018. 
13. https://surayadimpanel.wordpress.com. [Online] 2016.

14. A.Z., Zainal. Cara Terbaik Membangun Rumah. Jakarta : Gramedia Pustaka Utama, 2005. 15. Admin. http://www.spssstatistik.com. [Online] 2018. [Dikutip: 23 Juli 2018.]
Surya. 16. Akmal, Imelda, Arimbi, Novi dan Primasanti, Nadia. Bata Kuat, Awet, Indah dan Eksotis. Jakarta : Gramedia, 2010.

17.

Alfari,

Shabrina. https://www.arsitag.com/article/kenali-jenisdan-fungsi-batu-bata. [Online] 2018. [Dikutip: 8 Juli 2018.] 